Article

\title{
Comparative Studying of Leaf Trichomes, Teeth and Glands in Populus nigra L., Populus deltoides W. Bartram ex Marshall and Their Hybrids
}

\author{
Tatiana A. Feodorova ${ }^{1}$ and Oleg S. Alexandrov ${ }^{2, *}$ \\ 1 Higher Plant Department, Faculty of Biology, Lomonosov Moscow State University, Leninskie Gory 1, b. 12, \\ 119234 Moscow, Russia; torreya@mail.ru \\ 2 Laboratory of Plant Cell Engineering, All-Russia Research Institute of Agricultural Biotechnology, \\ Timiryazevskaya 42, 127550 Moscow, Russia \\ * Correspondence: alexandrov@iab.ac.ru or olegsandrov@gmail.com; Tel.: +7-499-976-6544
}

Received: 26 October 2020; Accepted: 25 November 2020; Published: 27 November 2020

\begin{abstract}
Poplars from Aigeiros Duby section are very widespread in the world. A range of morphological characters were studied in such species of this section as Populus deltoides Bartram ex Marshall, P. nigra L. and their hybrid P. $\times$ canadensis Moench. However, there is little information about micromorphological characters of their leaves. The aim of this work was to study these characters and understand their species-specific potential. Thus, the morphological features, density and distribution of non-glandular trichoms, marginal glandular trichomes (salicoid teeth or coleters), epiglandular trichomes and basilaminar nectaries-glands were ontogenetically examined by both light and scanning electron microscopy in the certified by molecular markers P. deltoides, P. nigra and $P . \times$ canadensis samples. Non-glandular trichomes belong to the uni-, multicellular, uniseriate category. Marginal glandular trichomes can be classified as coleter types. Other morphological and anatomical trichome features are discussed with regard to their possible function. In summary, some variations in leaf morphology may be useful for the P. nigra, P. deltoides and their hybrid $P$. $\times$ canadensis species identification. These species differ in shape and number of basilaminar glands, as well as non-glandular trichome types and their distribution on the leaf.
\end{abstract}

Keywords: Populus deltoides; Populus nigra; Populus $\times$ canadensis; micromorphology; trichomes; glandular trichomes; non-glandular trichomes; basilaminar glands; microscopy; molecular identification

\section{Introduction}

Populus nigra L. from Aigeiros Duby section is the most widespread Eurasian poplar. Primary ranges of P. nigra and P. deltoides Bartram ex Marshall (from the same section) do not overlap, but $P$. deltoides was introduced to Eurasia, and it produced fertile hybrids with P. nigra named $P . \times$ canadensis Sympatric species of the same section may freely cross and produce first-generation hybrids, which tend to last for decades, due to vegetative reproduction via root suckers or shoot layering. In turn, these hybrids may hybridize with one of the parents. At the same time, their genomes alter due to the crossing over during the meiosis. An assessment of hybrids' spread is a challenge. Hybrids are often identified as one of the parent species, as the range of character variability in the species remains undefined.

Major morphological diagnostic characters may be divided into vegetative and reproductive ones. The reproductive characters can be further divided into those of flowers and fruits. The reproductive characters are generally considered indicative and unambiguous. The vegetative ones are available for the most part of the phenological cycle, yet they are less helpful for identification, due to the lack of information about intraspesific variability of poplars and their hybrids. The recommendations for the 
representative material collection are based on the study of seasonal and ontogenetic heterophyllia (variations of leaf morphology along abbreviated and long shoots during the growing season) [1-3]. The poplar identification key based on leaf morphology will be more effective if it includes the characters of leaves formed in the autumn inside the buds (previously formed or "early" leaves), as well as those that are newly formed in late autumn, towards the end of the growing season (newly formed, or "late" leaves). However, the shaded branches of old trees often do not form any late leaves, which may distort the estimation of the heterophyllia within the species.

A set of trichome characters associated with leaf morphology is limitedly used for the diagnostics and in the classification of intrageneric groups of Populus. Ma et al., (2016) studied the genes related to trichome development in P. pruinosa Schrek. and P. euphratica Oliv., as well as the trichome location on leaves, stems, petioles and seed coats by scanning electron microscopy (SEM) [4]. The value of trichome parameters for taxonomy was emphasized by many authors [5-9]. In botanical studies, parameters such as type of trichomes [5,9-12], trichome density [12,13] or hair length [11,13] were commonly used. Depending on the investigated plant group, the trichome characters may be informative at the different taxonomic levels $[12,14]$. The differences in hair length were used to delimit taxa, e.g., Quercus faginea ssp. faginea and Q. faginea ssp. broteroi [15] and Q. canariensis, which were persistently distinct from other Quercus species [9]. On the other hand, Bartlott (1981) formulated the reasons why the features of trichomes were not successfully applied in taxonomy [16]. A number of authors have shown that the lack of data on ontogenetic development and the impact of the environment prevent the use of data on trichomes and hairs for systematic studies [13,16-18]. Consequently, there is a need to study the dependence of characters on the influence of the habitat, as well as to compare with other data to determine the taxonomic value.

In addition to leaf trichomes, salicoid teeth and glands are widely used as important diagnostic and taxonomic characteristics in plant taxonomy and studied in poplars. The first report about salicoid teeth as producing resin was made by Hanstein (1868) on the example of Populus [19]. Their secretory function was also described for P. balsamifera L. and P. laurifolia Ledeb. by Reinke (1876) [20]. Tschirch (1906, cit. by Fehér, 1923) described secretion and teeth in P. alba L., P. balsamifera, P. $\times$ canadensis, P. deltoides, $P$. $\times$ canescens, $P$. nigra [21,22]. Trelease (1881) reported about the "nectar" release by at $P$. balsamifera, P. candicans Aiton, P. grandidentata Michx., P. monilifera Ait., P. tremuloides Michx. and P. tremula L. from salicoid teeth [23].

Additionally, the basal glands are an important taxonomic character within the Populus genus. Studying of the leaf morphology in P. deltoides clones from all regions of the distribution area showed that the leaves of northern clones did not have or have few basal glands on the first leaves, whereas the southern clones have four or more basal glands on a leaf [24]. Such conclusions (Marcet's hypothesis), however, are the result of a small number of observations. It is possible that the timing for collecting the leaves was wrong. The leaves of the southern clones were unfurled earlier than the northern clones and therefore were at later stage of development already with several basal glands. Marcet's hypothesis has to be reconsidered with these reasoning.

Unfortunately, it is not easy to identify pure P. deltoides, P. nigra and P. $\times$ canadensis samples using morphological features only. Therefore, we used the set of morphological characters together with the data of molecular analysis with species-specific markers. The development of such markers was carried out by different authors in poplars [25-27]. Vornam et al., (1994) used some poplar hybrids with $P$. deltoides and P. nigra (controlled crosses between reference clones was carried out by Müller-Starck in Germany [28,29]) as a female parent to find the species-specific polymorphism in their chloroplast DNA (cpDNA). As a result, these authors found such polymorphism in one of the cpDNA regions with the XbaI enzyme digestion. This polymorphism was used in the article of Holderegger et al., (2005) to the discrimination of P. nigra from P. deltoides and P. $\times$ canadensis in Switzerland [26]. According to the article, the polymorphic regions was amplified with $\operatorname{tr} n \mathrm{~L} / \operatorname{trn} \mathrm{F}$ primers and digested by RsaI enzyme. In the case with P. nigra, the PCR product was not digested by the enzyme and the $1070 \mathrm{bp}$ fragment was observed. The PCR products of $P$. deltoides and $P$. $\times$ canadensis were digested to the $370 \mathrm{bp}$ and 
$700 \mathrm{bp}$ fragments. In the same work, Holderegger et al. also used the nuclear species-specific markers. One of them is win3. The primers of this marker were designed by Bradshaw et al., (1994) at the basis of the win3 gene, which was identified by Hollick and Gordon as a wound-mediated poplar gene having sequence similarity to Kunitz-type trypsin inhibitors [30,31]. Three years ago, Heinz (1997) successfully used the win3 primers for discernment of alleles in P. nigra, P. deltoides and their hybrids [25]. It was found that win3 is an effective codominant marker showed one $265 \mathrm{bp}$ PCR fragment in P. deltoides, one or two fragments or smear at approximately. 165-210 bp in P. nigra and a combination of both patterns in their hybrids. Thus, the described markers ( $\operatorname{trn} \mathrm{L} / \operatorname{trn} \mathrm{F} / \mathrm{Rs} \mathrm{I}$ and win3) are really valuable molecular tools for the species identification in poplars from the Aigeiros section, because they was created with the accurately identified plant material (reference clones from leading European collections and hybrids from the controlled cross families). This fact was a reason to use these markers in our work for facilitating the identification of samples by morphological characters. We believe that the plant material verified by the molecular method increased the reliability of the correspondence between the observed micromorphological features of leaves and the studied poplar species.

With the described approach, we were able to achieve the following goals in our work. First, we have reliably documented the types and distribution of trichomes in P. nigra, P. deltoides and their hydrid $P . \times$ canadensis to provide accessible and validated information for taxonomycal, phylogenetical and evolutional investigations. Second, we studied the anatomical and morphological structure of trichomes at different stages of leaf development in reliably identified poplar species from the Aigeiros section. The value of the features discovered in this way is high, since the glandular trichomes (salicoid teeth and basilaminar glands) can necrotize or disappear early, causing confusion in species identification by keys.

\section{Materials and Methods}

\subsection{Plant Materials}

Three species of Populus genus (Populus nigra L., P. nigra var. italica Münchh. (=P. nigra L. ssp. pyramidalis Čelak.), P. deltoides W. Bartram ex Marshall. ssp. monilifera (Ait.) Eckenw., P. deltoides W. Bartram ex Marshall. ssp. deltoides and P. $\times$ canadensis Moench.) were collected. The latter species is believed to be the result of briding or natural hybridization between P. nigra and P. deltoides. P. nigra is an early-succession tree species common in Euroasia and P. deltoides is a tree species common in North America.

Experimental trees of P. nigra were collected from their natural habitat of Lower Volga, Kuban' and Moscow region in the field during the field investigations between May and July in 2018-2019 years, and were immediately fixed in ethyl alcohol (70\%), in herbarium or grown under greenhouse conditions. Voucher specimens were collected for all taxa examined and are listed in Table S1 and were kept in MW. All fresh material used in the SEM study was collected shoots of known wild origin obtained from other collectors, as well as the cultivation of botanical gardens in greenhouses and experimental sites of the Russian State Agrarian University. All cultivated taxa are listed in the Table S1. Collectors' names and numbers are also indicated in the case of samples provided by individuals or groups.

\subsection{Light Microscopy (LM)}

Morphological and light methods were used for the study of salicoid teeth of fresh materials in ontogenesis, basal glands and pubescens features and trichomes types of P. nigra, P. deltoides and possible hybrid $P$. $\times$ canadensis. Two-three perennial long shoot (auxiblast with 5-7 perennial short shoots) and brachyblasts were collected from each threes. All young leaves (1 cm in length) were used for indicating activity of marginal and basilaminar trichomes. For the micromorphological studies, there were cut out three small $55 \mathrm{~mm}^{2}$ squares from the central part of the adaxial and abaxial leaf surfaces, including the midrib, and from the leaf edge. The exact density of trichomes was not 
calculated, because of their uneven distribution within a leaf and the high variation within and between leaves. The trichomes and indumentum features were classified using the terminology of Payne (1978) to describe the trichomes of Populus in this study [32]. Indumentum types were identified according to those recognized by Hewson (2019) [33]. All observations of indumentum presence, abundance and type were confined to the surface of the lamina (including margins). Leaves were considered to be glabrous when no sign of any trichomes could be seen (including on the midrib) with a light microscope or SEM.

The observations were carried out on a Zeiss microscope. In order to examine the trichome types, the paradermal sections of fresh material were cut out with a razor blade and explored with a Zeiss microscope. In solitary acicular and ribbon trichomes investigations, the length and width (at the widest point) were measured and the number of cells per trichome was determined on SEM and LM photographs. The additional observations were made with a light microscope on herbarium specimens, as well as on potted plants. In the latter case, both young and mature leaves were analyzed.

\subsection{Scanning Electron Microscopy (SEM)}

The samples grown under nature and greenhouse conditions, as well as the specimens fixed in herbarium in the field or fresh were dehydrated in a graded ethanol or acetone series, critical point-dried with $\mathrm{CO}_{2}$, mounted on aluminum stubs using double-sided sticky tape and coated with a thin layer of gold-platinum under vacuum. The types, morphology of trichomes and indumentums were examined with SEM (scanning electron microscope JEOL JSM-840) using secondary-electron detection and an acceleration voltage of $4-5 \mathrm{kV}$ (Laboratory of Electron Microscopy of MSU, East Lansing, MI, USA).

\subsection{PCR Analysis and Electrophoresis}

DNA extraction from all samples (Table S1) was conducted according to the protocol of Doyle and Doyle (1990), with some modifications [34,35]. The concentration of DNA in samples was equalized. DNA quality was tested by preliminary PCR with a universal primer pair based on $5 S$ rRNA gene (see Table S2) by Falistocco et al., (2007) [36].

The species-specific PCR tests were conducted with nuclear win3 and plastid $\operatorname{trn} \mathrm{L} / \operatorname{trn} \mathrm{F}$ markers. The primers are presented in Table S2. The primers were synthesized by ZAO "Synthol" (Moscow, Russia). The PCR conditions in experiments with the win 3 marker were as follows: $94^{\circ} \mathrm{C}$ for $3 \mathrm{~min}$, followed by 30 cycles of $94^{\circ} \mathrm{C}$ for $1 \mathrm{~min}, 50^{\circ} \mathrm{C}$ for $1 \mathrm{~min}$ and $72{ }^{\circ} \mathrm{C}$ for $1 \mathrm{~min}$, with a final extension of $72{ }^{\circ} \mathrm{C}$ for $4 \mathrm{~min}$. The PCR conditions in experiments with the $\operatorname{trn} \mathrm{L} / \operatorname{trn} \mathrm{F}$ marker (the used in these experiments primers for amplification of the $t r n \mathrm{~L} / \mathrm{tr} n \mathrm{~F}$ cpDNA region were designed by Taberlet et al., (1991) [37]) were as follows: $95^{\circ} \mathrm{C}$ for $3 \mathrm{~min}$, followed by 35 cycles of $94{ }^{\circ} \mathrm{C}$ for $1 \mathrm{~min}, 56^{\circ} \mathrm{C}$ for $1 \mathrm{~min}$ and $72{ }^{\circ} \mathrm{C}$ for $2 \mathrm{~min}$, with a final extension of $72{ }^{\circ} \mathrm{C}$ for $10 \mathrm{~min}$. The PCR mix volume is $25 \mu \mathrm{L}$. It contained approximately $10 \mathrm{ng}$ of genomic DNA, 2.5 U Taq-polymerase (ZAO “Sibenzyme", Novosibirsk, Russia), $1 \times$ SE-buffer, $2.5 \mathrm{mM} \mathrm{MgCl}_{2}, 100 \mu \mathrm{M}$ of each dNTP, $0.25 \mu \mathrm{M}$ of forward and reverse primer and ddH2O. The digestion of the $\operatorname{trn} \mathrm{L} / \mathrm{trn} \mathrm{F}$ PCR products was carried out in $20 \mu \mathrm{L}$ reaction volume with $20 \mathrm{U}$ of $R s a \mathrm{I}$ restriction enzyme in $1 \times$ restriction buffer at $37^{\circ} \mathrm{C}$ overnight. PCR and restriction results were detected by electrophoresis on $2.5 \%$ agarose gel at $10 \mathrm{~V} / \mathrm{cm}$ in $0.5 \mathrm{M}$ TBE buffer using a Sub-Cell Model 192 camera (Bio-Rad, Hercules, CA, USA) and photographed using the gel documentation system GelDoc XR Plus (Bio-Rad, Hercules, CA, USA).

\section{Results}

\subsection{PCR Analysis with Molecular Markers}

The win 3 and $\operatorname{trn} \mathrm{L} / \operatorname{trn} \mathrm{F}$ markers showed the presence of the amplification in all studied samples The picture of the win3 amplification results corresponded to Heinz's discription [25]. The P. nigra samples had patterns with one fragment $170 \mathrm{bp}$ in length. The differences between P. nigra and P.nigra var. italica were not found. The samples of P. deltoides ssp. monilifera and P. deltoides ssp. deltoides 
had patterns with one $260 \mathrm{bp}$ fragment. All $P . \times$ canadensis samples showed both $170 \mathrm{bp}$ and $260 \mathrm{bp}$ fragments in their patterns (Figure 1a). The trnL/trnF marker were not present the differences between P. nigra and P.nigra var. italica samples. The expected $1070 \mathrm{bp}$ fragments were observed in these samples after the PCR product digestion by RsaI enzyme. In contrast to this case, the $\operatorname{trn} \mathrm{L} / \mathrm{trnF}$ marker identified diffences between $P$. deltoides ssp. monilifera and P. deltoides ssp. deltoides samples. The P. deltoides ssp. deltoides products were as it was described by Holderegger et al., (2005) for P. deltoides trees [26]. The $370 \mathrm{bp}$ and $700 \mathrm{bp}$ fragments were detected. However, all P. deltoides ssp. monilifera samples had one fragment approximely $710 \mathrm{bp}$ in length. All studied $P . \times$ canadensis trees showed patterns of products which were similar with $P$. deltoides ssp. deltoides (Figure 1b).

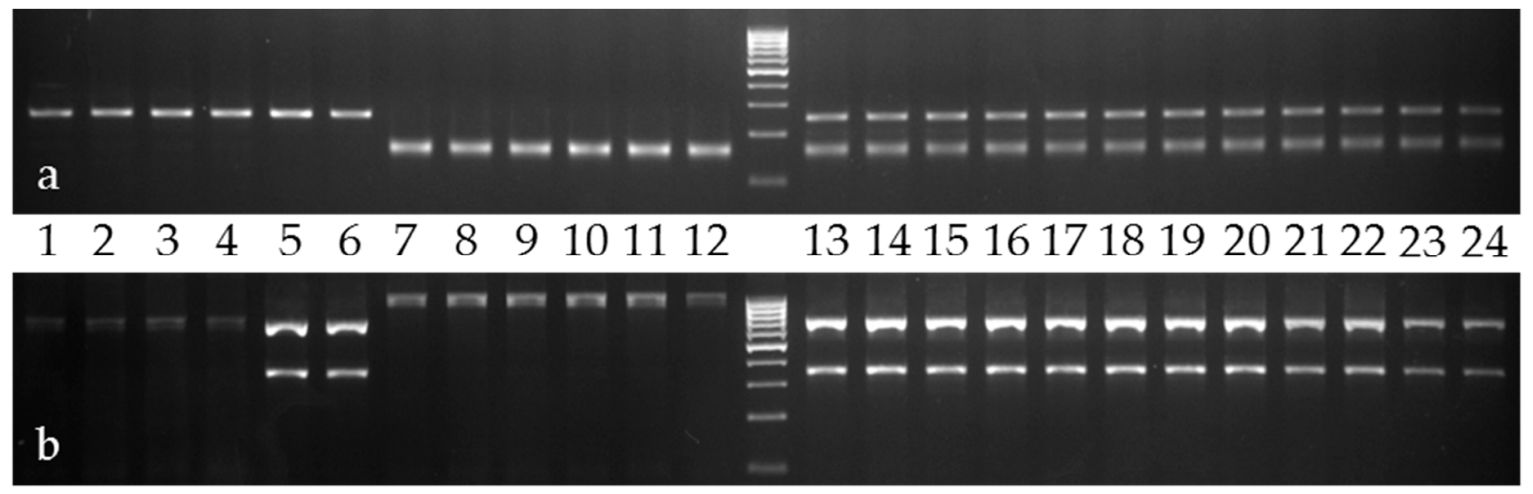

Figure 1. The results of win3 (a) and $\operatorname{trn} \mathrm{L} / \operatorname{trn} \mathrm{F}(\mathbf{b})$ marker experiments with $P$. deltoides ssp. monilifera (1-4), P. deltoides ssp. deltoides (5,6), P. nigra (7-11), P.nigra var. italica (12) and P. $\times$ canadensis (13-24) samples. The marker of molecular weight has a $100 \mathrm{bp}$ step. The numbers of samples correspond to Table S1.

\subsection{Morphological Analysis}

The authors made an attempt to collect and analyze a representative set of samples, taking into consideration all the listed above and newly discovered facts. At the early stages of leaf ontogenesis, the marginal glands may not be fully developed, while the trichomes are already fully developed; at the later stages of ontogenesis, leaves may have glands, but no longer have trichomes [38,39]. In this connection, the correct research requires leaves of different categories: leaves on early ontogenesis stage, leaves on late ontogenesis stage, leaves of abbreviated shoots, leaves of long shoots. Leaves of these categories differ in shape and size, as well as in micromorphological characters (shape and size of their marginal teeth, pubescence density, presence/absence of bazilaminar glands).

In this study, two general trichome types in Populus have been found: glandular and non-glandular. Glandular trichomes include marginal glands (colleter) and bazilaminar nectariferous glands. They differ in cell number, length, shape. Non-glandular trichomes can be acicular and ribbon. Acicular trichomes occur mostly on the abaxial midrib or sometimes on the entire abaxial surface of the leaf. We distinguished two types of acicular trichomes in the Populus: long and short. Long and short trichomes consisted of a single stalk cell. The surface ornamentation of the trichome body was smooth. Ribbon trichomes can be also of two types: long and short. They are flattened and have a shape as a flowing ribbon. However, they do not persist into the adult stage in all species. Simple trichomes represented in mature leaves are usually short, often curved and closely appressed to the leaf surface. Though the base of the trichome is usually swollen, there is generally little or no cell differentiation of the surrounding epidermal cells. It is possible that the simple trichomes longer than $400 \mu \mathrm{m}$ always have one cell of the base. 


\subsubsection{The Features of P. nigra Samples}

Marginal Glands

In P. nigra samples, salicoid teeth consist of glandular roundish spherical or hemispherical and extended apical part, subapical contraction and basis (Figure S1a). The glandular part is presented by palisade-like epidermal cells which secrete resin (Figure S1b).

The glandular part carries trichomes of different forms and lengths (Figure S2a-1). Possibly, these trichomes increase surface for transpiration and transpiration induced increasing of apoplastic solutes in palisade-like cells for resin secretion. Later, the palisade-like cells are lignified and reduced. Subapical contraction is presented by the elongate cells.

Later, epiglandular trichomes and the glandular part of trichomes reduces and, therefore, were not noticed by the researchers earlier (Figure S3b).

The basis of teeth is covered with epidermal cells and one-two stomata as a relict feature (Figure S5a), which is similar to Idesia polycarpa one adaxial hydathode [40]. Belin-Depoux (1989) considered that nectary and hydathode are relictual and "the foliar glandularization is considered as more recent than hydatherous elements from phylogenetical point of view" [40]. Possibly, a specific unspecialized type of hydathode may act as nectary in specific conditions [41]. P. nigra has one vascular bundle per tooth (Figure S3c). The spiral and poriferous elements of a xylem end in tips (Figure S3d). Venation is eukamptodromous. The verge is between salicoid teeth of the leaf (Figure S3e). The verge is represented by several rows of cells without chloroplasts which perform mechanical function.

Basilaminar Nectaries-Glands

It was generally accepted that glands or nectarines are absent at leaf base or on the petiole of P. nigra. Most leaves have no glands on the leaf basis (Figure S4a,b). Some samples have basal glands or glands near the petioles (Figure S4c,d). The surface of basilaminar glands is smooth. This species has heterophyllous leaves: most leaves without basilaminar glands and a minor number of leaves carry basilaminar glands.

\section{Non-Glandular Trichomes}

We studied leaves of P. nigra of several ontogenetic stages. The adaxial surface of a young leaf with a diameter about $1 \mathrm{~cm}$ has smooth short simple unicellular acicular trichomes of 50-100 $\mu \mathrm{m}$ long (Figure S5a-c) and $5 \mu \mathrm{m}$ thick and medium acicular trichomes 100-200 $\mu \mathrm{m}$ long (Figure S5d,e). The trichomes longer than $250 \mu \mathrm{m}$ are ribbon (Figure S5f). The abaxial surface of veins, leaf basis and petiole have acicular and ribbon trichomes more often.

\subsubsection{The Features of $P$. deltoides ssp. deltoides Samples}

\section{Marginal Glands}

The glandular part of salicoid teeth has different forms and is presented by palisade-like epidermal cells which secrete resin (Figure S6). The glandular part carries epiglandular short acicular trichomes of ciliate indumentum. These trichomes fall off later. Subapical contraction is presented by the elongate cells. The basal part of salicoid teeth and verge of leaf are covered by acicular trichomes. One bundle ends near the base of the tooth and includes spiral elements of a xylem.

\section{Basilaminar Nectaries-Glands}

Two-three large stalked nectaries glands are located at the leaf base or at the petiole for resin and nectar secretion (Figure S7). 


\section{Trichomes}

The marginal part of leaf is ciliate, it has smooth short acicular trichomes 50-100 $\mu \mathrm{m}$ long and $5 \mu \mathrm{m}$ thick (Figure S6a-c). The abaxial and adaxial surfaces, veins, basis of leaf are glabrous (Figure S7d). The petioles have short acicular trichomes $50-100 \mu \mathrm{m}$ long and very rare long ribbon trichomes 500-1000 $\mu \mathrm{m}$ long (Figure S7e,f).

\subsubsection{The Features of P. deltoides ssp. moniliferae Samples}

\section{Marginal Glands}

The glandular part of salicoid teeth has different forms and is presented by palisade-like epidermal cells which secrete resin (Figure S8a-d). The glandular part carries epiglandular short acicular trichomes of ciliate indumentum. These trichomes fall off later. Subapical contraction is presented by the elongated cells. Basal part of salicoid teeth and margins of leaf are covered by acicular trichomes. One bundle ends near the base of the tooth and includes spiral elements of a xylem.

\section{Basilaminar Nectaries-Glands}

Two basilaminar nectaries-glands are located at the leaf base or at the petiole for resin and nectar secretion. The surface of glands is covered by smooth short acicular trichomes $100 \mu \mathrm{m}$ long and $5 \mu \mathrm{m}$ thick (Figure S8d).

Trichomes

The marginal part of leaf is ciliate (Figure S9a-c) with smooth short acicular trichomes of 50-100 $\mu \mathrm{m}$ long and $5 \mu \mathrm{m}$ thick and long acicular and ribbon trichomes of 500-1000 $\mu \mathrm{m}$ long (Figure S9a,b). The abaxial and adaxial surfaces, veins, basis of leaf are covered with rare short acicular (Figure S9c,d) and long ribbon trichomes (Figure S9e). The petioles have short acicular trichomes of 50-100 $\mu \mathrm{m}$ long and very rare long ribbon trichomes of 500-1000 $\mu \mathrm{m}$ long as in P. deltoides ssp. deltoides samples (Figure S7e,f).

\subsubsection{The Features of $P . \times$ canadensis Samples}

\section{Marginal Glands}

The glandular part of salicoid teeth has triangular or spherical forms and is presented by palisade-like epidermal cells, which secrete resin (Figure S10a). The glandular part carries epiglandular trichomes of various shapes and lengths (Figure S10b,c). The basis of teeth covered with epidermal cells and one-two stomata as a relict feature. Later the palisade-like cells are lignified and epiglandular trichomes and glandular part of trichomes are reduced (Figure S10d). Therefore, they were not noticed by the researchers earlier. One bundle ends near the base of the tooth and includes spiral elements of the xylem. The verge is between salicoid teeth of leaf. The border is represented by several rows of cells without chloroplasts which perform mechanical function.

\section{Basilaminar Nectaries-Glands}

One or sparsely two glands can be located at the leaf base or at the petiole for resin and nectar secretion. The surface of glands is covered with smooth short acicular trichomes $100 \mu \mathrm{m}$ long and $5 \mu \mathrm{m}$ thick (Figure S11a).

\section{Trichomes}

The edge, adaxial and abaxial surfaces of $P . \times$ canadensis leaves are covered with sparse smooth short acicular trichomes 50-100 $\mu \mathrm{m}$ long and ribbon trichomes 500-1000 $\mu \mathrm{m}$ long and $5 \mu \mathrm{m}$ thick (Figure S11b,c). The veins and leaf petioles have trichomes more often (Figure S11d-f). The P. $\times$ canadensis 
samples have marginal part of leaves with smooth short acicular trichomes, which form ciliate indumentum. The basis, petiole and basal marginal part of late leaf do not have trichomes.

\subsubsection{The Observed Indumentum Types in Studied Poplars}

We furthermore discerned four main indumentum types of young leaves of the P. nigra, P. deltoides and $P . \times$ canadensis:

1. Strigose indumentum. The leaf surface is covered with appressed, rigid, bristle-like, straight trichomes, or is often confined to the lamina and the midrib of the leaf (Figure S12a-c).

2. Pilose indumentum. The leaf surface is covered with hairs which are soft, weak, thin and clearly separated. The hairs are usually defined as long and sometimes ascending (Figure S12d-f).

3. Ciliate indumentum. The leaf has fine eyelash-like hairs at the edge (Figure S12c).

\section{Discussion}

In this work, we used two molecular markers to validate the species of the studied samples. The nuclear marker win3 worked as it was presented by Heinz and Holderegger et al., (2005) [25,26]. However, the second marker (the plastid marker $\operatorname{trn} \mathrm{L} / \operatorname{trn} \mathrm{F}$ ) showed the interesting picture in P. deltoides ssp. monilifera and P. deltoides ssp. deltoides samples. Holderegger et al., (2005) described such results as we observed in P. deltoides ssp. deltoides trees [26]. However, the P. deltoides ssp. monilifera results were untypical (we detected one fragment approximately $710 \mathrm{bp}$ in length instead of two expected $370 \mathrm{bp}$ and $700 \mathrm{bp}$ fragments). We found out for the first time that the used $t r n \mathrm{~L} / t r n \mathrm{~F}$ marker can work this way. In our opinion, it would be promising to conduct an in-depth study of $\operatorname{trn} \mathrm{L} / \operatorname{trn} \mathrm{F}$ region among a large number of $P$. deltoides trees of different subspecies in a separate publication. First, it is necessary to establish precisely that the observed fragment is not a nonspecific artifact of PCR. Second, it is important to examine the sequence of the region to be amplified to explain the observed work of the marker. Additionally, the $\operatorname{trn} \mathrm{L} / \operatorname{trn} \mathrm{F}$ marker allowed us to conclude that one of the parents of the studied $P . \times$ canadensis samples was $P$. deltoides ssp. deltoides.

We observed non-glandular and glandular trichomes on all two Populus species from Aigeiros section (P. deltoides, P. nigra, and their hybrid P. $\times$ canadensis). The non-glandular trichomes did not show a wide morphological variability; they all represent uniseriate, uni- and/or oligocellular trichomes-short and long acicular and short and long ribbon. Unicellular short acicular trichomes are the most simple ones to be found in P. deltoides, P. nigra, $P . \times$ canadensis and, possibly, the oldest in this genus. Long acicuar trichomes are common type of $P$. deltoides, $P$. nigra, $P . \times$ canadensis, but are rare on the leaves' surfaces. P. nigra and $P . \times$ canadensis species present a characteristic arrangement of rare non-glandular long ribbon trichomes on abaxial surface. P. deltoides and $P . \times$ canadensis species present a characteristic arrangement of rare non-glandular short ribbon trichomes on marginal part of leaves.

P. deltoides and P. $\times$ canadensis have ciliate marginal indumentum. P. nigra do not have ciliate marginal indumentum. $P$. deltoides ssp. deltoides have stalked basilaminar glandular trichomes. P. deltoides ssp. moniliferae have sessile basilaminar glandular trichomes. The complex characters (basilaminar glands and ciliate indumentum) identify P. deltoides species. The ciliate indumentum without basilaminar glands identifies $P . \times$ canadensis. The blades without ciliate indumentum and basilaminar glands characterize P. nigra.

In the case of glandular trichomes (collectors), the ancestral features of trichomes can be reconstructed by the structure of the former Flacourtiaceae. This, apparently, is a transformation from sessile marginal glands of Flacourtiaceae and Salicaceae into complex stalked basilaminar nectaries-glands of Populus deltoides. Possibly, stalked nectaries-glands are derived from sessile nectaries-glands and arise independently in some Salicaceae taxa.

The epiglandular trichomes are common glandular trichomes for P. nigra and P. $\times$ canadensis and possibly represent a variety of hydathodes [42,43]. The epiglandular trichomes of Populus deltoides are short and acicular. They form a part of the continuous ciliate indumentum. This is likely due to an 
adaptive trait often exhibited in resin secreting plants to increase the active water secretion of glandular trichomes. Our data correlate with the opinion of Ponzi and Pizzolongo (1992) for Rhinanthus minor and Odontites vema [44,45], who wrote that glandular trichomes, participating in the active secretion of water as trichome hydathodes, direct solutions from the stem to the young parts of the shoot.

The earlier studies did not find all trichome types reported here. We have described, for the first time, that poplar's young leaves have straight, non-glandular trichomes (acicular and ribbon) in addition to marginal and basilaminar glandular trichomes. The early and late leaves are formed in different seasons, but they develop in the same vegetative season. The dense trichome becomes thinner with leaf size increasing. During the foliage transition from a juvenile to an adult form, the trichomes of adaxial and abaxial surfaces fall off, and the basilaminar and marginal glandular trichomes are destroyed. The presence of dimorphic indumentum (juvenile leaves with non-glandular trichomes and nude adult leaves) is often mistakenly used as a diagnostic and taxonomic character. The short needle-like trichomes of the marginal hairs of the cilia of $P$. deltoides and $P$. $\times$ canadensis persist for a long time and bring $P$. deltoides closer to balsamic poplars. Therefore, a clear distinction between the two species groups can be suggested here. Taking into account the characteristic features of indumentum, the adopted sectional subdivision of the genus Populus looks artificial.

Nevertheless, the pubescence and trichome types are characters of a diagnostic significance. Short and long ribbon trichomes are the feature of P. nigra; those short ribbon trichomes are typical for $P$. deltoides along with cilia at the margin. P. deltoides ssp. deltoides and ssp. moniliferae confidently differ in basilaminar gland types (stalked in ssp. deltoides and sessile in ssp. moniliferae) and their quantity. In the $P$. deltoides and $P$. nigra hybrid $(P . \times$ canadensis $)$ two types of trichomes occur: short and long needle-like, while marginal cilia are facultative. Basilaminar glands cannot be used for identification of the hybrid, as their occurrence overlaps in the involved species.

The presence of several types of $P$. nigra trichomes is probably the evidence of an ancient hybridogenic origin of this species, one of its parents may be a poplar of balsamic group.

The plant trichomes can be used for the taxonomy of species of Aigeiros section (for example, see Table 1). There is no clear presense/absence of the trichome type pattern that could allow a unambiquous taxon delimitation, because all types are present in all the three species ( $P$. deltoides, P. nigra; P. $\times$ canadensis). The exception is the lack of long ribbon trichomes in P. deltoides. These trichomes are the derivates of acicular trichomes as a basic type. Each trichome type can include several groups with different size. This can be the distinguishing characteristic between taxa. In contrast, ciliate foliar indumentums, especially the persistence of trichomes on the marginal side of the leaves, differentiates the American and Eurasian groups in the Aigeiros section. P. $\times$ canadensis consistently differs from both species in that it has all the characteristics of both types of trichomes, and is probably a hybrid adapted to wider climatic conditions. We believe that a large number of American P. deltoides and $P . \times$ canadensis samples, covering the entire distribution area, should be studied to capture natural variation. Such studies will provide more knowledge about evolutionary issues and the origin of various types of trichomes and their functional properties in the Populus genus. 
Table 1. The major trichomes diagnostic features of the Aigeiros section poplars.

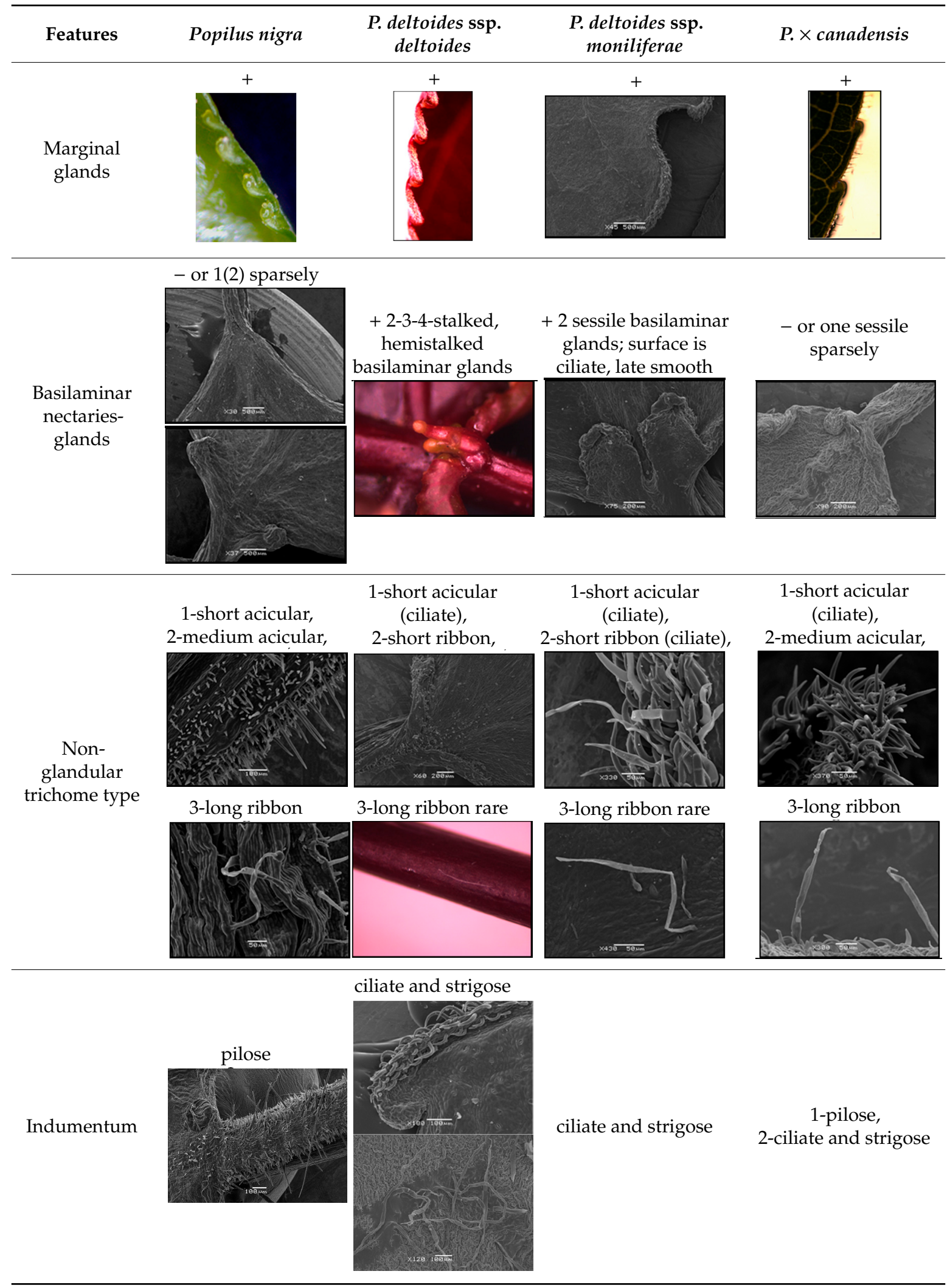

\section{Conclusions}

In this work, we formulated a whole range of morphological and anatomical features of the leaf, which can distinguish the studied species: shape and number of basilaminar glands, non-glandular 
trichome types and their distribution on the leaf. P. deltoides ssp. deltoides leaves have big stalked and hemistalked basilaminar glands ( $P$. deltoides ssp. moniliferae also have big basilaminar glands, but they are sessile) and P. nigra sparsely have small sessile basilaminar glands (often, basilaminar glands are absent). The presence of ciliate type of indumentum in P. deltoides is a clear character that discretize this species and P. nigra which have not ciliate trichomes. In $P . \times$ canadensis leaves, these features are selectively combined. Basilaminar glands in this hybrid are as in P. nigra and it have ciliate trichomes as $P$. deltoides.

Supplementary Materials: The following are available online at http://www.mdpi.com/1999-4907/11/12/1267/s1, Table S1: Poplar trees samples, origin, collectors and Herbarium voucher location and number, Table S2: The used molecular markers and their characteristics, Figure S1: Marginal glands of P. nigra, Figure S2: Differences in forms and lengths of glandular parts of $P$. nigra marginal glands, Figure S3: The external and internal structure of salicoid teeth of $P$. nigra, Figure S4: Leaves of $P$. nigra without basilaminar glands and with basilaminar glands, Figure S5: Trichomes on P. nigra leaves, Figure S6: Edge, basal part and petiole of $P$. deltoides ssp. deltoides leaves, Figure S7: Basilaminar glands, abaxial surface and petiole of $P$. deltoides ssp. deltoides leaves, Figure S8: The micromorphological features of P. deltoides ssp. moniliferae leaves, Figure S9: Trichomes of P. deltoides ssp. moniliferae leaves, Figure S10: The features of edge of $P . \times$ canadensis leaves, Figure S11: Glands and trichomes of $P . \times$ canadensis leaves, Figure S12: Types of leaf indumentum.

Author Contributions: T.A.F. and O.S.A. created main ideas of work, conceived and designed the experiments and formulated the discussion; T.A.F. collected plant materials, conducted microscopy investigations and wrote the paper; O.S.A. collected plant materials, performed the PCR experiments, analyzed the data, corrected and supplemented the text of the paper. All authors have read and agreed to the published version of the manuscript.

Funding: This work was supported by the Russian Foundation for Basic Research, contract No. 19-04-00744\20 of March 31, 2020.

Acknowledgments: The authors are grateful to A.N. Sorokin (Department of tropical and subtropical plants, Main Botanical Garden named by N.V. Tsitsin, RAS), D.A. Ipatova (student of Biology department, Moscow State University), staff of Herbarium of Lomonosov Moscow State University (MW) and Herbarium of Main Botanical Garden named by N.V. Tsitsin, RAS (MHA), staff of Laboratory of Electron Microscopy of MSU, T.V. Alexandrova for critically reading the English version of the manuscript, and two anonymous reviewers for helpful comments that improved this manuscript.

Conflicts of Interest: The authors declare no conflict of interest.

\section{References}

1. Critchfield, W.B. Leaf dimorphism in Populus trichocarpa. Am. J. Bot. 1960, 47, 699-711. [CrossRef]

2. Eckenwalder, J.E. Foliar heteromorphism in Populus (Salicaceae) a source of confusion in the taxonomy of Tertiary leaf remains. Syst. Bot. 1980, 5, 366-383. [CrossRef]

3. Eckenwalder, J.E. Taxonomic signal and noise in multivariate interpopulational relationships in Populus mexicana (Salicaceae). Syst. Bot. 1996, 21, 261-271. [CrossRef]

4. Ma, J.; He, X.; Bai, X.; Niu, Z.; Duan, B.; Chen, N.; Shao, X.; Wan, D. Genome-wide survey reveals transcriptional differences underlying the contrasting trichome phenotypes of two sister desert poplars. Genes 2016, 7, 1-17. [CrossRef] [PubMed]

5. Schwarz, O. Entwurf zu einem natürlichen system der cupuliferen und der gattung Quercus L. Notizbl. Bot. Gart. Berlin-Dahlem 1936, 13, 1-22. [CrossRef]

6. Uphof, J.C.T. Plant hairs. In Encyclopedia of Plant Anatomy. V. IV, Part 5, 2nd ed.; Zimmermann, W., Ozenda, P.G., Eds.; Handbuch der Pflanzenanatomie. Borntraeger: Berlin, Germany, 1962; pp. 1-206.

7. Napp-Zinn, K. Anatomie des Blattes: II. Blattanatomie der Angiospermen, A. Entwicklungsgeschichtliche und Topographische Anatomie der Angiospermenblattes; Lieferung. Borntraeger.: Berlin, Germany, 1973.

8. Judd, W.S.; Campbell, C.S.; Kellogg, E.A.; Stevens, P.F. Plant Systematics: A Phylogenetic Approach; Sinauer Associates Inc.: Sunderland, MA, USA, 1999; p. 464.

9. Tschan, G.F.; Denk, T. Trichome types, foliar indumentum and epicuticular wax in the Mediterranean gall oaks, Quercus subsection Galliferae (Fagaceae): Implications for taxonomy, ecology and evolution. Bot. J. Linn. Soc. 2012, 169, 611-644. [CrossRef]

10. Llamas, F.; Perez-Morales, C.; Acedo, C.; Penas, A. Foliar trichomes of the evergreen and semi-deciduous species of the genus Quercus (Fagaceae) in the Iberian Peninsula. Bot. J. Linn. Soc. 1995, 117, 47-57. [CrossRef] 
11. Bussotti, F.; Grossoni, P. European and Mediterranean oaks (Quercus L.; Fagaceae): SEM characterization of the micromorphology of the abaxial leaf surface. Bot. J. Linn. Soc. 1997, 124, 183-199. [CrossRef]

12. Uzunova, K.; Palamarev, E.; Ehrendorfer, F. Anatomical changes and evolutionary trends in the foliar epidermis of extant and fossil Euro-Mediterranean oaks (Fagaceae). Plant Syst. Evol. 1997, 204, 141-159. [CrossRef]

13. Buys, N.H. The systematic value of the leaf indumentums in Lobostemon (Boraginaceae). Bothalia 2005, 35, 93-99. [CrossRef]

14. Jones, J.H. Evolution of the Fagaceae: The implications of foliar features. Ann. Mo. Bot. Gard. 1986, 73, 228-275. [CrossRef]

15. Amaral Franco, J. Quercus L. In Flora Ibérica. II. Plantas Vasculares de la Península Ibérica e Islas Baleares; Castroviejo, S., Laínz, M., López, G., Montserrat, P., Muñoz, F., Paiva, J., Villar, L., Eds.; RJBM-CSIC: Madrid, Spain, 1990; pp. 16-36.

16. Barthlott, W. Epidermal and seed surface characters in plants; systematic applicability and some evolutionary aspects. Nord. J. Bot. 1981, 1, 345-355. [CrossRef]

17. Levins, M.R. A revision of Lobostemon. Bot. J. Linn. Soc. 1934, 49, 393-451.

18. Bramwell, D. A revision of the genus Echium in Macaronesia. Lagascalia 1972, 2, 37-115.

19. Hanstein, J. Überdie organe der harz-und schleim-absonderung in der Lauknospen. Bot. Ztg. 1868, 26, 697-713, 721-736, 745-761, 769-787.

20. Reinke, J. Beiräge zur anatomie der an laubblättern, besonders an den zähnen. Derselbem vorkommenden secretions-organe. Jahrb. Wiss. Bot. 1876, 10, 119-178.

21. Tschirch, A. Die Harze und die Harzbehälter Mit Einschluss der Milchsäfte; Historisch-Kritische und Experimentelle in Gemeinschaft mit Zahlreichen Mitarbeitern Ausgeführte Untersuchungen, Stark Erweiterte Aufl; Verlag Von Gebrüder Bornträger: Leipzig, Germany, 1906; p. 1268.

22. Fehér, D. Über die absceidung von harzbalsam auf den jungen trieben unserer einheimischen Populus-Arten. Beih. Bot. Centralbl. 1923, 39, 81-103.

23. Trelease, W. The foliar nectar glands of Populus. Bot. Gaz. 1881, 6, 284-290.

24. Marcet, E. Über die geographische variabilitait blatt-morphologischer merkmale bei Populus deltoides Bartr. Silvae Genet. 1961, 10, 161-177.

25. Heinze, B. A PCR marker for a Populus deltoides allele and its use in studying introgression with native European Populus nigra. Belg. J. Bot. 1997, 129, 123-130.

26. Holderegger, R.; Angelone, S.; Brodbeck, S.; Csencsics, D.; Gugerli, F.; Hoebee, S.E.; Finkeldey, R. Application of genetic markers to the discrimination of European black poplar (Populus nigra) from American black poplar (P. deltoides) and hybrid poplars (P. × canadensis) in Switzerland. Trees 2005, 19, 742-747. [CrossRef]

27. Alexandrov, O.S.; Karlov, G.I. Development of $5 S$ rDNA-based molecular markers for the identification of Populus deltoides Bartr. ex Marshall, Populus nigra L., and their hybrids. Forests 2018, 9, 604. [CrossRef]

28. Vornam, B.; Herzog, S.; Preisigmuller, R.; Hattemer, H.H. Restriction-fragment-length-polymorphisms of a chloroplast photosystem-II gene from poplar and their use for species identification. Genome 1994, 37, 747-750. [CrossRef]

29. Müller-Starck, G. Genetic control and inheritance of isoenzymes in poplars of Tacamahaca section and hybrids. Silvae Genet. 1992, 41, 87-95.

30. Bradshaw, H.D., Jr.; Villar, M.; Watson, B.D.; Otto, K.G.; Stewart, S.; Steller, R.F. Molecular genetics of growth and development in Populus. III. A genetic linkage map of a hybrid poplar composed of RFLP, STS and RAPD markers. Theor. Appl. Genet. 1994, 89, 167-178.

31. Hollick, J.B.; Gordon, M.P. A poplar tree proteinase inhibitor-like gene promoter is responsive to wounding in transgenic tobacco. Plant Mol. Biol. 1993, 22, 561-572. [CrossRef]

32. Payne, W.W. A glossary of plant hair terminology. Brittonia 1978, 30, 239-255. [CrossRef]

33. Hewson, H.J. Plant Indumentum: A Handbook of Terminology, Revised Edition; Australian Biological Resources Study, Commonwealth Department of the Environment and Energy: Canberra, Australia, 2019; p. 47.

34. Doyle, J.J.; Doyle, J.L. Isolation of plant DNA from fresh tissue. Focus 1990, 12, 13-15.

35. Razumova, O.V.; Alexandrov, O.S.; Divashuk, M.G.; Sukhorada, T.I.; Karlov, G.I. Molecular cytogenetic analysis of monoecious hemp (Cannabis sativa L.) cultivars reveals its karyotype variations and sex chromosomes constitution. Protoplasma 2016, 253, 895-901. [CrossRef] 
36. Falistocco, E.; Passeri, V.; Marconi, G. Investigations of 5S rDNA of Vitis vinifera L.: Sequence analysis and physical mapping. Genome 2007, 50, 927-938. [CrossRef]

37. Taberlet, P.; Gielly, L.; Pautou, G.; Bouvet, J. Universal primers for amplification of three non-coding regions of chloroplast DNA. Plant Mol. Biol. 1991, 17, 1105-1109. [CrossRef] [PubMed]

38. Feodorova, T.A. Leaf trichomes, teeth and glands of the some Populus species (Salicacae). Plant anatomy: Traditions and perspectives. In Proceedings of the Materials of the International Symposium Dedicated to the 90th Anniversary of Prof. Ludmila Ivanovna Lotova, Moscow, Russia, 16-21 September 2019; Timonin, A.C., Sokoloff, D.D., Eds.; In Two Parts, Part 1. Contributions in English. MAKS Press: Moscow, Russia, 2019; pp. 76-80.

39. Feodorova, T.A.; Aleksandrov, O.S. Significance of leaf morphological characters in diagnostics and taxonomy of black and white poplars (sections Populus and Aigieros Duby). Skvortsovia 2020, 6, 16-18.

40. Belin-Depoux, M. Aspects histologiques des glandes foliares de l'Idesia polycarpa Maxim. (Flacourtiaceae). Rev. Gen. Bot. 1982, 89, 11-120.

41. Curtis, J.D.; Lersten, N.R. Morphology, seasonal variation, and function of resin glands on buds and leaves of Populus deltoides (Salicaceae). Am. J. Bot. 1974, 61, 835-845. [CrossRef]

42. Scherffel, A. Die drüsen in den höhlen der rhizomschuppen von Lathraea squamaria L. Mitt. Bot. Ins. Gras. 1888, 1, 187-211.

43. Ziegler, H. Lathraea, ein blutungssaftschmarotzer. Ber. Deutsch. Bot. Ges. 1955, 68, 311-320.

44. Ponzi, R.; Pizzolongo, P. Structure and function of Rhinanthus minor L. trichome hydathode. Phytomorphology 1992, 42, 1-6.

45. Govier, R.N.; Brown, J.G.S.; Pate, J.S. Hemiparasitic nutrition in angiosperms. II. Root haustoria and leaf glands of Odontites verna (Bell.) Dum. and their relevance to the abstraction of solutes from the host. New Phytol. 1968, 678, 963-972. [CrossRef]

Publisher's Note: MDPI stays neutral with regard to jurisdictional claims in published maps and institutional affiliations.

(C) 2020 by the authors. Licensee MDPI, Basel, Switzerland. This article is an open access article distributed under the terms and conditions of the Creative Commons Attribution (CC BY) license (http://creativecommons.org/licenses/by/4.0/). 